大日本セルロイド株式侖能・1950年 2 月 4 日受理

\title{
(18〜19] 有機酸エステル系可塑劑の研究（IＩI）
}

第1報フタール酸エステルの合成

村上恭本

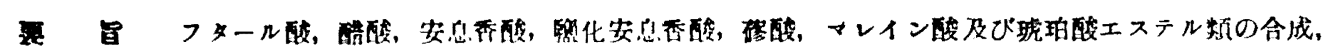

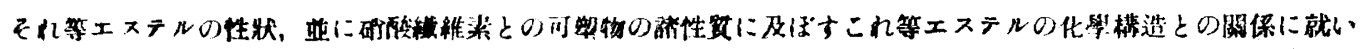
て研究した。

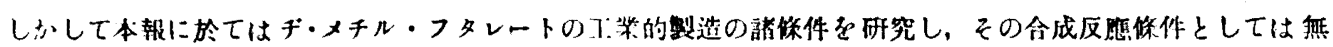

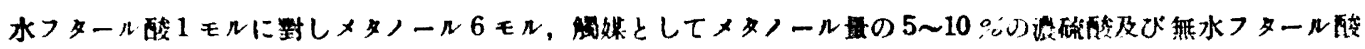

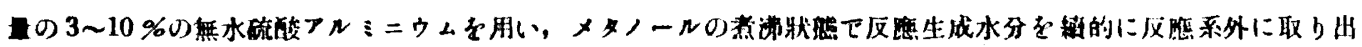

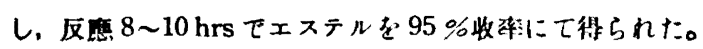

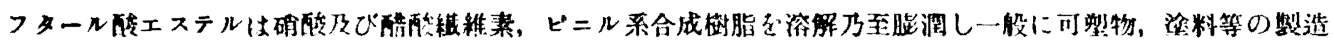

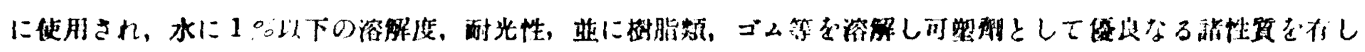

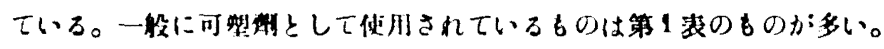

\section{第1衰フタール酸エステル}

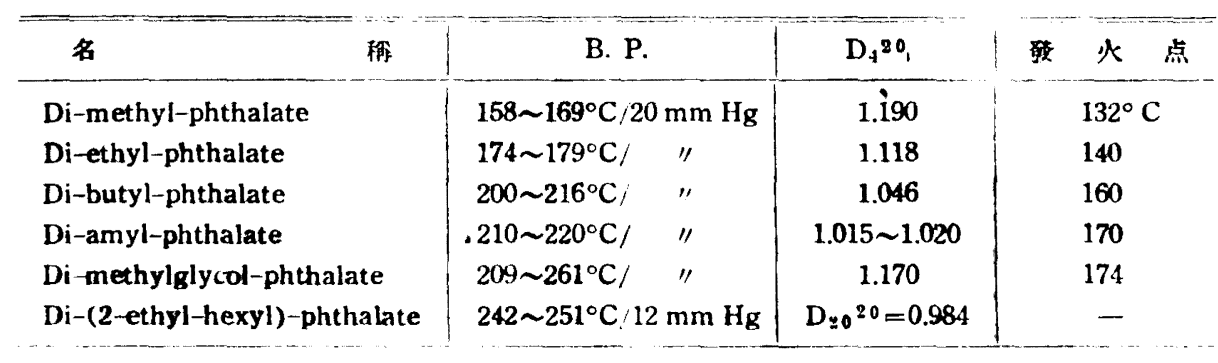

\section{-}

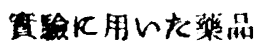

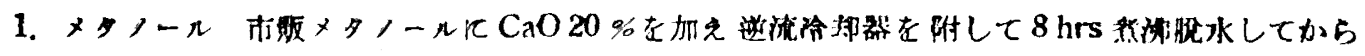
精留する。 $\mathrm{D}_{4}^{15}=0.7977$ (99.7 \%)

2. 無水フタール酸 National Aniline Co. 製热色針狀結晶 m. p. $=134 \sim 135^{\circ} \mathrm{C}$

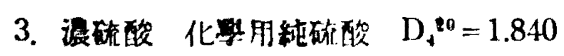

4. 無水硫酸フルミニウム

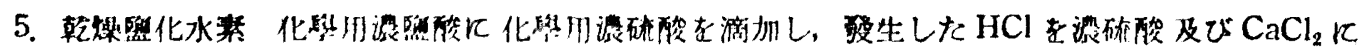
て乾煤メタノールに吸收さす。

慗 (第 1 润) 


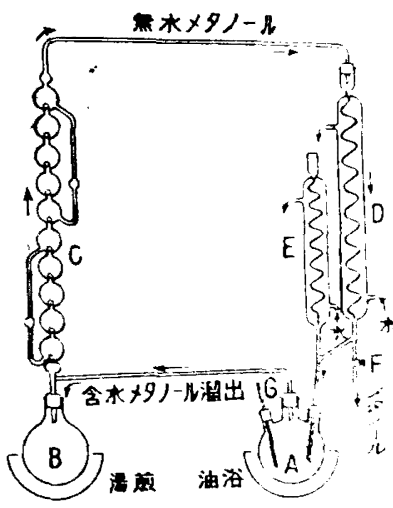

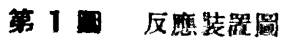
$\mathrm{A}$ ：反㫿フラスコ $\mathrm{D}$ : 冷却管
$\mathrm{B}$ ：蒸溜フラスコ $\mathrm{E}$ ：冾却管
C：分浽管
$\mathrm{G}$ : 寒榎計

探 作

フラスコ A ル $\mathrm{HCl}$ の所姴量を吸收させたメタノール或は所要量 の硫酸及び哭水硫酸フルミニウムを含むメタノールと哭水フタール 酸を加え， アラスコ Bに注 $\mathrm{CaO} 500 \mathrm{~g}$ を加え或は加えすして，フ

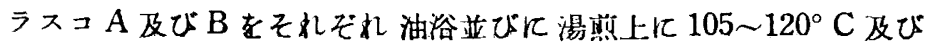
80 9 $0^{\circ} \mathrm{C}$ に加熱して所要時間後に Fより過剩のメタノールを溜出

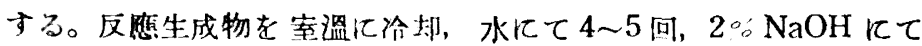
その洗媇液かフェノール・フタレンイて弱厂ル力リ性となるまで洗。 潫する。最啳に 1 回水洗し, 各洗液よりエーテルにて少量のエステ ル分を抽出し，主ェステル分汇加えてから減留分留してそのエステ ル溜分を以つてェステルの゙牧量とした。

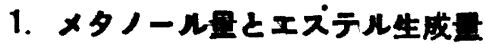

無水フタール酸 $148 \mathrm{~g}(1$ モル) 及びその $10 \%$ 量の $\mathrm{HCl}$ を含むメタノールをフラスコ $\mathrm{A}$ に入れ，

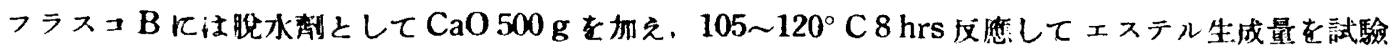
した。

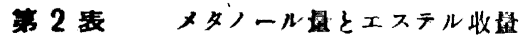

\begin{tabular}{|c|c|c|c|}
\hline 無水フタール酸（g） & $x \not,-n(g)$ & エステル收费（g） & エステル收率 (分) \\
\hline $148(1 \mathrm{Mol})$ & $128(4 \mathrm{Mol})$ & 176 & 90.72 \\
\hline $148(" \prime)$ & $160(5 \mathrm{Mol})$ & 178 & 91.75 \\
\hline $148(")$ & $192(6 \mathrm{Mol})$ & 180 & 92.78 \\
\hline $148(" \prime)$ & $256(8 \mathrm{Mol})$ & 181 & 93.30 \\
\hline $148(\prime \prime)$ & $384(12 \mathrm{Mol})$ & 182.5 & 94.07 \\
\hline $148(" \prime)$ & $576(18 \mathrm{Mol})$ & 183 & 94.33 \\
\hline $148(" /)$ & 768 (24 Mol) & 185 & 95.36 \\
\hline $148(" \prime)$ & $960(36 \mathrm{Mol})$ & 184 & 94.86 \\
\hline
\end{tabular}

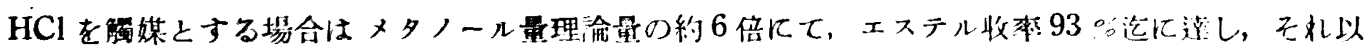
上堆加するも收率は特に盘加著しくない。

\section{2. 反應時間とエステル收量}

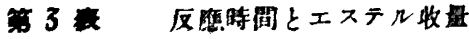

\begin{tabular}{|c|c|c|}
\hline 反㮣時阔 $(h r)$ & エステル敏量（g） & エステル收事: $(\%)$ \\
\hline 4 & 514 & 88.32 \\
\hline 6 & 520 & 89.35 \\
\hline 8 & 528 & 90.72 \\
\hline 10 & 533 & 91.58 \\
\hline 12 & 536 & 92.10 \\
\hline 14 & 539 & 92.61 \\
\hline
\end{tabular}

無水フタール酸 $444 \mathrm{~g}(3$ モル)及び $17 \mathrm{~g}$ 郎与 $3 \%$ のCl を含有するメ夕 ノール $576 \mathrm{~g}(18$ モル)を所要時䦥反 應させェステル收易を試驗した。

反應時間は $8 \mathrm{hrs}$ で良くそれ以上長

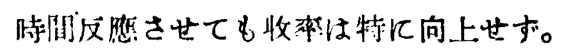




\section{HGl 量とエステル收量}

メタノールに各種量の $\mathrm{HCl}$ ガスを吸收せしめて反應した場合, その $\mathrm{HCl}$ 量とェステル收量を試驗 した。但し反應 $8 \mathrm{hrs}$.

第 4 褧 $\mathrm{HCl}$ 些とエステル收揘

\begin{tabular}{|c|c|c|c|c|}
\hline 無水フタール酸（g） & メタノール（g) & $\mathrm{HCl}(\mathrm{g})$ & エステル收指（g） & エステル收秦: $(\%)$ \\
\hline $296(2 \mathrm{Mol})$ & $1152(36 \mathrm{Mol})$ & $15(1.3 \%)$ & 357 & 92.03 \\
\hline $296(" \prime)$ & $1152(" \prime)$ & $30(2.6 \%)^{-}$ & 366.5 & 94.46 \\
\hline $296(" \prime)$ & $1152(" \prime)$ & $35(3.0 \%)$ & 364.4 & -93.92 \\
\hline $296(" \prime)$ & $1152(" \prime)$ & $35(3.0 \%)$ & 362.3 & 93.38 \\
\hline $296(" \prime)$ & $512(16 \mathrm{Mol})$ & $15.5(3.0 \%)$ & 359.5 & 92.66 \\
\hline $296(" \prime)$ & $512(" \prime)$ & $25.5(5.0 \%)$ & 364 & 93.81 \\
\hline $296(" \prime)$ & $640(20 \mathrm{Mol})$ & $38.5(6.0 \%)$ & 360 & 92.78 \\
\hline
\end{tabular}

䚡媒 $\mathrm{HCl}$ 量俚メタノール量の $3 \%$ にて充分である。

\section{4. $\mathrm{H}_{2} \mathrm{SO}_{4}$ 觸 媒}

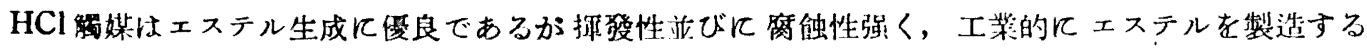
埸合に装置その他不經猚であるから，操作简單な硫酸觸媒の作用を試驗した。

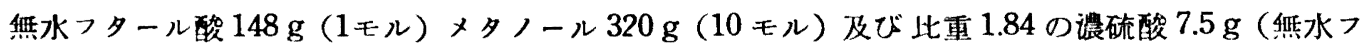

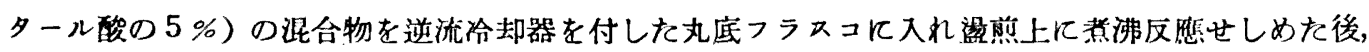
椧却粉末 $\mathrm{BaO} 14 \mathrm{~g}$ を加え $\mathrm{H}_{2} \mathrm{SO}_{4}$ を $\mathrm{BaSO}_{4}$ として沈澱してから，過剩メタノールを溜出せしめその

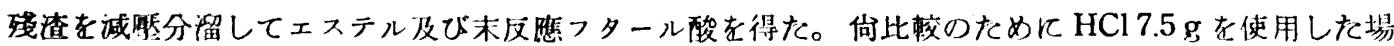
合の結果を併記した。

第 5 类 $\mathrm{H}_{2} \mathrm{SO}_{4}$ 䑦媒による反腹時間とエステル收证

\begin{tabular}{|c|c|c|c|}
\hline 成㮣時间 (hrs) & エステル收拉（g） & エステル收率（\%) & 㺫收フタール酸 $(\mathrm{g})$ \\
\hline 2 & 86 & 44.33 & 75 \\
\hline 4 & 108 & 55.66 & 55 \\
\hline 8 & 112 & 60.82 & 53 \\
\hline . $\quad 12$ & 120 & 61.86 & 51 \\
\hline 16 & 127 & 65.46 & 41 \\
\hline $\mathrm{HCl} 7.5 \mathrm{~g} .8 \mathrm{hrs}$ & 172 & 88.66 & 5 \\
\hline
\end{tabular}

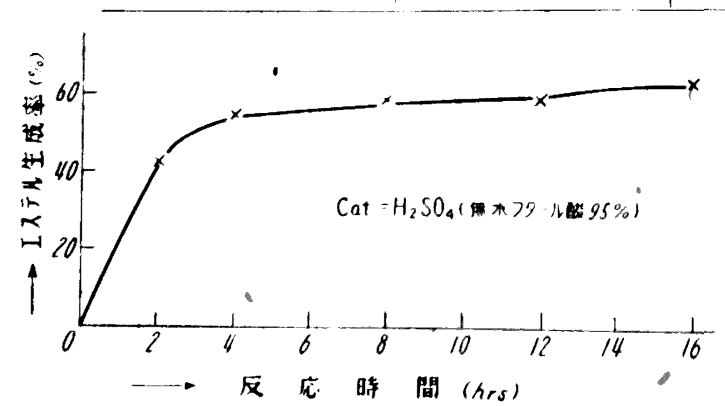

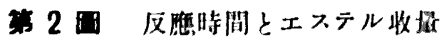

$\mathrm{H}_{2} \mathrm{SO}_{4}$ の触媒効果は $\mathrm{HCl}$ より些しく 劣るがその反應速度喟は $\mathrm{HCl}$ のそれに酷 似している。

\section{〔A〕エステル生誠速度}

Commercial Solvent Co. U. P. 1695449 (1928) は硫酸丁ルミニウムを共

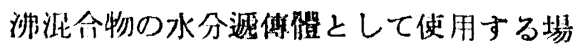


台にェステル生成量が增加するとなしている。依つて $\mathrm{H}_{2} \mathrm{SO}_{4}$ 觸媒に $\mathrm{Al}_{2}\left(\mathrm{SO}_{4}\right)_{3}$ を眖水觸媒として併 用しェステルの生成速酖を試驗した。郎ちメタノール $260 \mathrm{~g}$, 無水フタール酸 $74 \mathrm{~g}, \mathrm{H}_{2} \mathrm{SO}_{4}$ (此重 1.84) $16 \mathrm{~g}$ 及び無水硫酸フルミニウム $7.5 \mathrm{~g}$ の混合物を三つ口丸底フラスコス入れ, 逆流冷却器を付 し湯煎上飞煮坲して各時間每に一定試料を取り $24 \sim 25^{\circ} \mathrm{C}$ 於て, 5 c.c. の試料に N/2 KOH $(\mathrm{F}=$ 0.922) を滴定して>タール酸の減少狀態を測定した。

第 6 表エステル生成速经

\begin{tabular}{|c|c|c|c|c|c|}
\hline 反 漹 & 時 間。(hr) & $\mathrm{N} / 2 \mathrm{KOH}$ 量 (c.c.) & 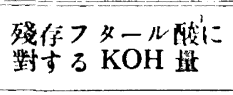 & 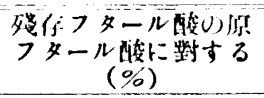 & $\begin{array}{l}\text { エステル } \\
\text { 化线 }(0,0)\end{array}$ \\
\hline \multicolumn{2}{|c|}{ メタノール $+\mathrm{H}_{2} \mathrm{SO}_{4}+\mathrm{Al}_{2}\left(\mathrm{SO}_{4}\right)_{3}$} & 6.35 & - & - & - \\
\hline \multicolumn{2}{|c|}{ フタル陵完全涯加時 } & 29.20 & 22.85 & \multirow{2}{*}{$\begin{array}{r}100.00 \\
60.18\end{array}$} & 0 \\
\hline \multicolumn{2}{|c|}{ フタール酸完溶時(毒沸) } & 20.10 & 13.75 & & 39.82 \\
\hline 春沸 & 0.5 & $17.70^{\prime}$ & 11.35 & 49.67 & 50.33 \\
\hline " & 1 & 13.35 & 7.00 & 30.64 & 69.36 \\
\hline$" \prime$ & 2 & 12.40 & 6.05 & 26.48 & 73.52 \\
\hline$" 1$ & 3 & 11.40 & 5.05 & 22.10 & 77.90 \\
\hline " & 4 & 10.60 & 4.25 & 18.60 & 81.40 \\
\hline " & 5 & 10.00 & 3.65 & 15.97 & 84.03 \\
\hline " & 6 & 9.70 & 3.35 & 14.66 & 85.34 \\
\hline " & 7 & 9.50 & 3.15 & 13.79 & 86.21 \\
\hline " & 8 & 9.50 & 3.15 & 13.79 & 86.21 \\
\hline " & 9 & 9.55 & 3.20 & \multirow{2}{*}{$\begin{array}{l}14.00 \\
13.79\end{array}$} & 86.00 \\
\hline " & 12 & 950 & 3.15 & & 86.21 \\
\hline " & 16 & 9.55 & 3.20 & 14.00 & 86.00 \\
\hline
\end{tabular}

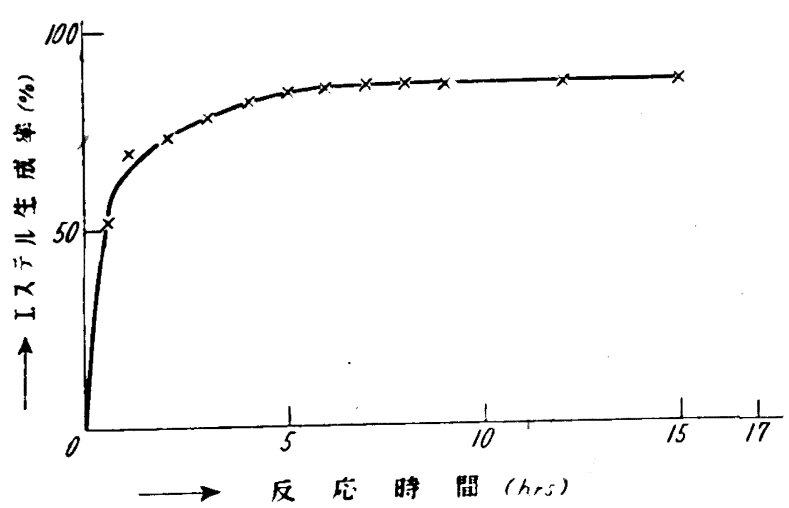

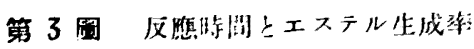

との反照條件ではェステル生成装86 \%である。

$$
\begin{aligned}
& \mathrm{C}_{6} \mathrm{H}_{4}\left\langle\mathrm{CO}_{\mathrm{CO}}^{\mathrm{CO}}>\mathrm{O}+2 \mathrm{CH}_{3} \mathrm{OH}\right. \\
& 148 \mathrm{~g} \\
& \rightleftarrows \mathrm{C}_{6} \mathrm{H}_{4} \underset{\mathrm{COOCH}_{3}}{\mathrm{COOCH}_{3}}+\mathrm{H}_{18} \mathrm{O} \\
& \mathrm{C}_{5} \mathrm{H}_{4}<\begin{array}{l}
\mathrm{CO} \\
\mathrm{CO}
\end{array}>\mathrm{O}=74 \mathrm{~g} \rightarrow \mathrm{H}_{2} \mathrm{O}=9 \mathrm{~g} \\
& \mathrm{Al}_{2}\left(\mathrm{SO}_{4}\right)_{3}+18 \mathrm{H}_{2} \mathrm{O} \\
& \rightarrow \mathrm{Al}_{2}\left(\mathrm{SO}_{4}\right)_{3} \cdot 18 \mathrm{H}_{2} \mathrm{O} \\
& 342 \mathrm{~g} \quad-324 \mathrm{~g} \\
& 7.5 \mathrm{~g} \quad-7.1 \mathrm{~g}
\end{aligned}
$$

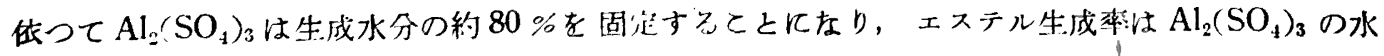
分固定率江近似倠である。

[B] $\mathrm{H}_{2} \mathrm{SO}_{4}$ 量とエステル收量

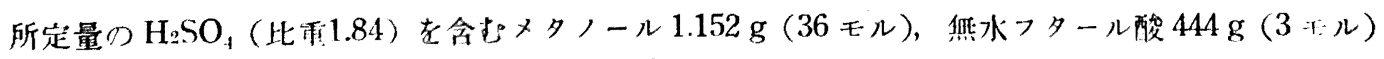
及び $\mathrm{Al}_{2}\left(\mathrm{SO}_{4}\right)_{3} 57 \mathrm{~g}$ （理淪生成水分に賞量）をフラスコ $\mathrm{A}$ 亿加え, フラスコ $\mathrm{B}$ には $\mathrm{CaO} 500 \mathrm{~g}$ を入 
れ前同栚炕してェステルを造る。

第 7 咅 $\mathrm{H}_{2} \mathrm{SO}_{4}$ 毞とエステル收姆

\begin{tabular}{|c|c|c|c|c|c|}
\hline \multicolumn{2}{|c|}{$\mathrm{H}_{2} \mathrm{SO}_{4}$ 量 $(\mathrm{g})$} & \multicolumn{2}{|c|}{$\mathrm{HCl}$ ガ $ᄌ$ 媓 (g) } & \multicolumn{2}{|c|}{ エステル收得（g） } \\
\hline 重虽（g） & $\begin{array}{l}\text { メタノールに } \\
\text { 對する(地) }\end{array}$ & 百i揕（g） & 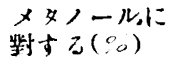 & Iff $(\mathrm{g})$ & 收率 $(\%)$ \\
\hline 115 & 10 & - & - & 532 & 91.41 \\
\hline 57 & 5 & - & - & 528 & 90.72 \\
\hline- & - & 35 & 3 & 529 & 90.90 \\
\hline - & - & 17 & 1.5 & 530 & 91.06 \\
\hline \multicolumn{2}{|c|}{$\mathrm{Al}_{2}\left(\mathrm{SO}_{4}\right)_{3}$ 苦含まず } & 35 & 3 & 528 & 90.72 \\
\hline
\end{tabular}

$\mathrm{Al}_{2}\left(\mathrm{SO}_{4}\right)_{3}$ 及び $\mathrm{H}_{2} \mathrm{SO}_{4}$ 觸煤で江 $\mathrm{HCl}$ 之同程度の成 緽が得られる。

$\mathrm{HCl}$ の場合は $\mathrm{Al}_{2}\left(\mathrm{SO}_{4}\right)_{3}$ の効果 は認められなん。

[C] $\mathrm{Al}_{2}\left(\mathrm{SO}_{4}\right)_{3}$ 量とェステル收量

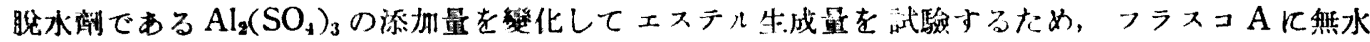

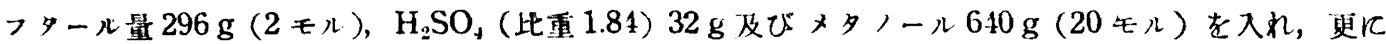

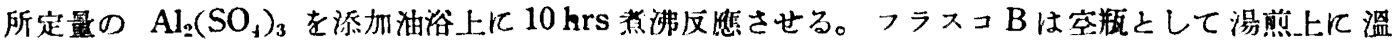

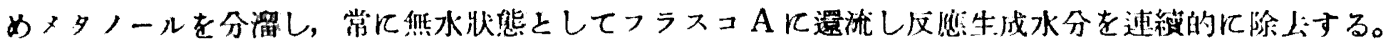

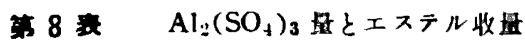

\begin{tabular}{|c|c|c|c|}
\hline \multicolumn{2}{|c|}{$\mathrm{Al}_{2}\left(\mathrm{SO}_{4}\right)_{3}$} & \multicolumn{2}{|c|}{ エステル } \\
\hline 重量（g） & 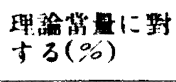 & 重量（g） & 牧等( \\
\hline - & - & 315 & 85.02 \\
\hline 9 & 23.7 & 350 & 94.46 \\
\hline 19 & 50.0 & 340 & 91.76 \\
\hline 38 & 100.0 & 327 & 88.25 \\
\hline 76 & 200.0 & 329 & 88.79 \\
\hline 152 & 400.0 & 330 & 89.06 \\
\hline
\end{tabular}

$\mathrm{Al}_{2}\left(\mathrm{SO}_{4}\right)_{3}$ 量は生成水分の理椧當量の 20 $50 \%$ ，䬦七盆水フタール酸に對し 3〜7\% 程度が技上のエステル收量を得られ，それ 以上の時は $\mathrm{Al}_{2}\left(\mathrm{SO}_{4}\right)_{3}$ 結晶內儿算水フター ル酸が多量包藏されると到りて、ェステル 收量を減少し且つ作業上にも多大の不便を 生する。

〔D〕反隹生成分を分溜に上り脢水して

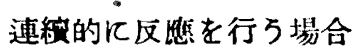

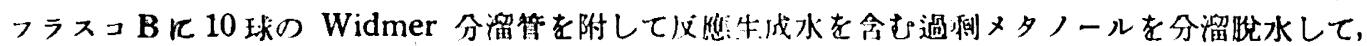

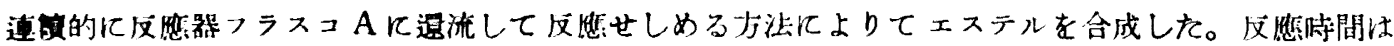

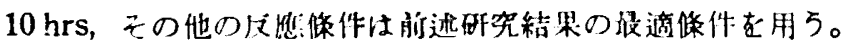

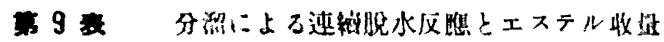

\begin{tabular}{|c|c|c|c|c|c|c|}
\hline $\mathrm{CH}_{\mathrm{CaO}}(\mathrm{g})$ & 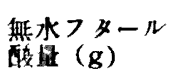 & ${ }_{(\mathrm{g})}^{-n}$ & $\underset{(\mathrm{g})}{\mathrm{H}_{2} \mathrm{SO}_{4} \text { 䜤 }}$ & $\underset{(\mathrm{g})}{\mathrm{Al}_{2}\left(\mathrm{SO}_{4}\right)_{3}}$ & $\begin{array}{c}\text { エステル是 } \\
(\mathrm{g})\end{array}$ & $\begin{array}{c}\text { エᄌテ儿收率: } \\
\left(\begin{array}{c}0 \\
0\end{array}\right)\end{array}$ \\
\hline- & 592 & 1024 & 102 & 57 & 706 & 90.98 \\
\hline 500 & 592 & 1024 & 102 & 57 & 709 & 91.37 \\
\hline- & 592 & 1024 & 75 & 57 & 704 & 90.72 \\
\hline 500 & 592 & 1024 & 75 & 57 & 709 & 91.37 \\
\hline- & 592 & 1280 & 64 & 57 & 708 & 91.24 \\
\hline 500 & 592 & $128^{\circ}$ & 61 & 57 & 702 & 90.47 \\
\hline - & 592 & 1280 & 61 & 112 & 712 & 91.75 \\
\hline- & $5 \% 2$ & ראל 1' & 61 & 28 & 720 & 92.78 \\
\hline- & 592 & 1280 & 64 & 14 & 722 & 93.04 \\
\hline - & $59 \%$ & 1280 & 6it & - & 622 & 80.16 \\
\hline
\end{tabular}




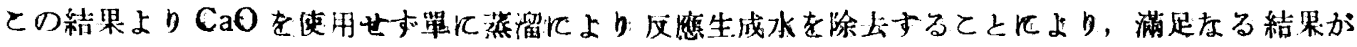
得られるととが明である。

\section{5. 總括}

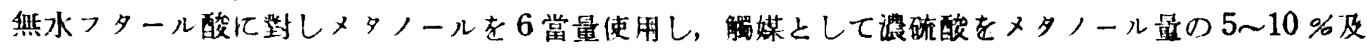

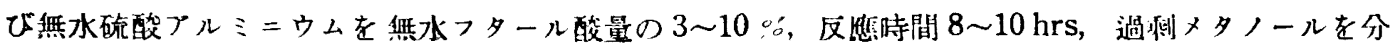

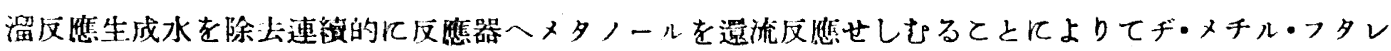
一ト 94 95\%收率䎲て得られる。

かくて得られたチ・メチれ・フタレートは

B. P. $\quad 150 \sim 153^{\circ} \mathrm{C} / 15 \mathrm{~mm} \mathrm{Hg}$ (或 $匚 282^{\circ} \mathrm{C} / 760 \mathrm{~mm} \mathrm{Hg}$ )

$\mathrm{D}_{4}{ }^{15} \quad 1.197$

战化価 $580 \sim 583$

变 $0.012 \sim 0.013 \%$ (

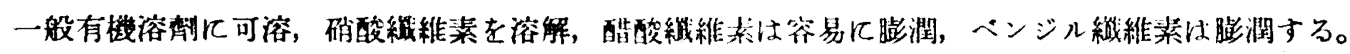

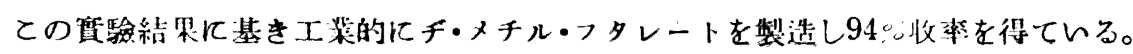

\section{6. ヂフテチル・フタレートの合成}

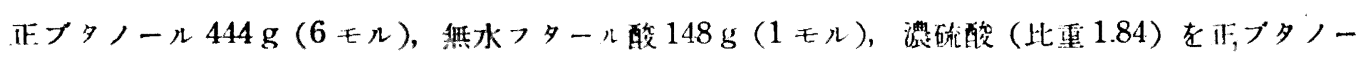

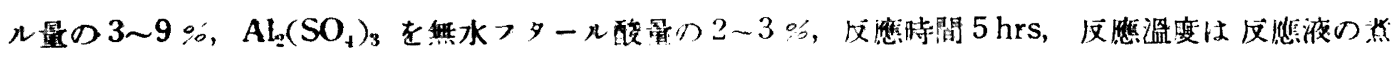

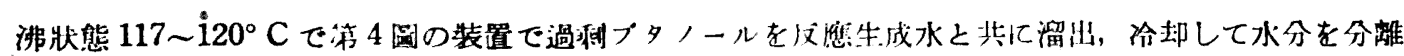

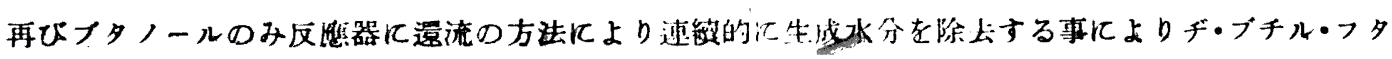
レートを 97〜98\%收䋃にて得た。

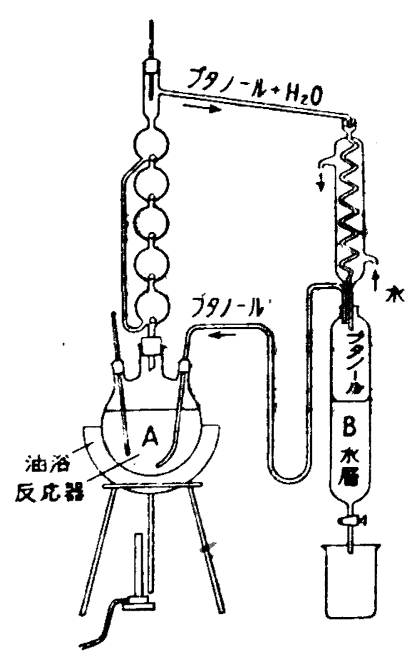

事 4 日エステル化裝㽡

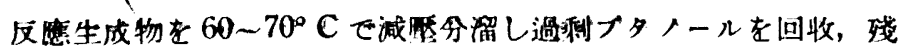

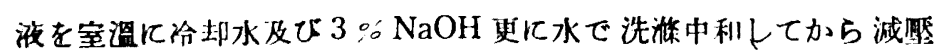
精渭し，エステルを拆る。

B. P. $203 \sim 205^{\circ} \mathrm{C} / 16 \sim 17 \mathrm{~mm} \mathrm{Hg}$

$D_{20}{ }^{20}=1.0479$

酸度 $0.003 \%(フ タ ー ル$ 酦として $)$

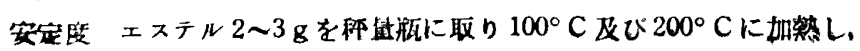

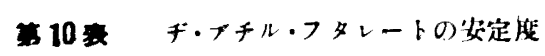

$(\because=フ$ タール酸として)

\begin{tabular}{|c|c|c|}
\hline 加熱時閪了 & 加 䓡 & 俵 \\
\hline hr. & $100 \pm 1^{\circ} \mathrm{C}$ & $200 \pm 1^{\circ} \mathrm{C}$ \\
\hline - & \multicolumn{2}{|c|}{$0.003 \%$ (加热せす，轻料) } \\
\hline 1 & 0.0346 响 & 0.994 \\
\hline 2 & 0.0387 & 2.628 \\
\hline 3 & 0.0372 & 2.946 \\
\hline
\end{tabular}

その㳀度を $\mathrm{N} / 10 \mathrm{NaOH}$

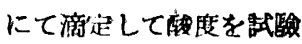
した。2000 C 加整により 著しく分解〉タール酸を 遊離ナる。

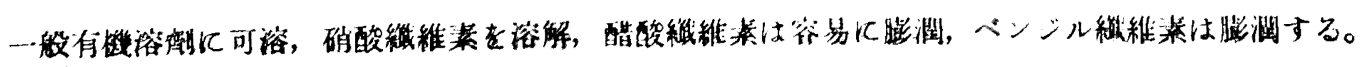


ての筫驗結果に基きてヂ・ブチル・フタレートを工菜的に製造し 95〜96\%收率を得た。

\section{7. フタール酸エステル製造原單位}

前報 (6) の反應條件によりて，ヂ・エチル・フタレート及びヂ-(2-ェチル・ヘキシル)ーフタレートの 製造を行ん，それ等の製造原單位は次の通りであつた。

第 11 咅 フタール酸エステル製䢨原單位（エステル $100 \mathrm{~kg}$ 常り）

\begin{tabular}{|c|c|c|c|c|c|c|}
\hline フタール酦エステル & 垈水フタール酸 & 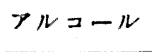 & ソーダ扊 & $\mathrm{H}_{2} \mathrm{SO}_{4}$ & 不 & ii \\
\hline ヂーエチル・フタレート & $85 \mathrm{~kg}$ & $68 \mathrm{~kg}$ & $15 \mathrm{~kg}$ & $17 \mathrm{~kg}$ & $160 \mathrm{~kg}$ & $100 \mathrm{KWH}$ \\
\hline ヂーブチル・フタレート & 56 & 65 & 6.5 & 4.3 & 163 & 105 \\
\hline $\begin{array}{l}\text { ヂ-(2-エチル・ヘキシル)・ } \\
\text { フタとート }\end{array}$ & 43 & 82 & 7.0 & 7.3 & 136 & 102 \\
\hline
\end{tabular}

但し, 石峞 $=6.000 \mathrm{Cal} . / \mathrm{kg}$

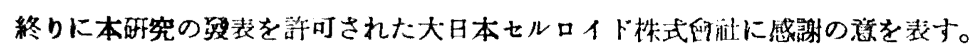

第 2 報 醮酸, 安息香酸, 監化安息香酸, 蓚酸,

マレイン酸及び琥珀酸エステルの合成

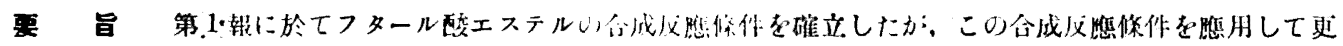
に,メタノール, 正-ブチルフルコール, イン・フミルフルコール, エチレン・クライコール, エチ・ン・クロロヒ ドリン, メトキシ・エチルフルコール, エトキシ・エチルフルコール, 正一フトキシ・エチルフルコール, フェノー ル,フェノキシ・エチルフルコール, oークロロ・フェノキシ・エチルフルコール，2.4-ヂ・クロロ・フェノキシ・エチ

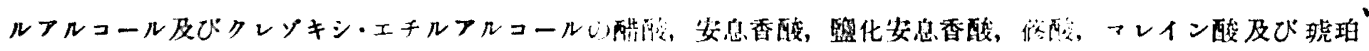

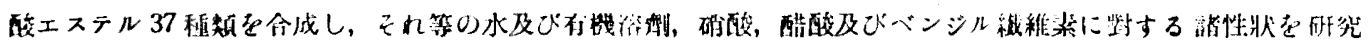
しだ。

\section{[筫駼]}

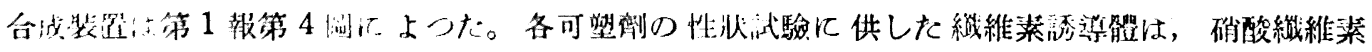

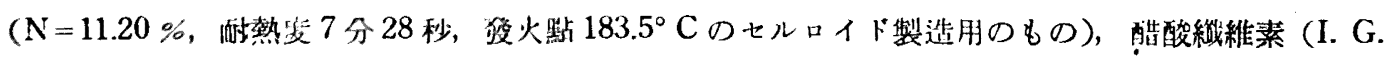

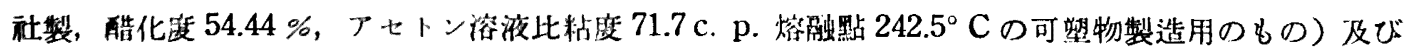

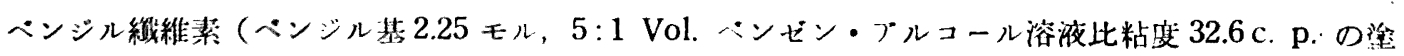
料州のもの)である。

\section{1. 醋酸エステルの合成}

1.フェノキシ・ェチル・アヒテート (Phenoxy-ethyl-acetate)

$\mathrm{C}_{6} \mathrm{H}_{5} \mathrm{O} \cdot \mathrm{C}_{2,} \mathrm{H}_{4} \mathrm{OH}+\mathrm{CH}_{3} \mathrm{COOH}=\mathrm{C}_{4:} \mathrm{H}_{5} \mathrm{OC}_{2} \mathrm{H}_{4} \mathrm{OCOCH}_{3}+\mathrm{H}_{2} \mathrm{O}$

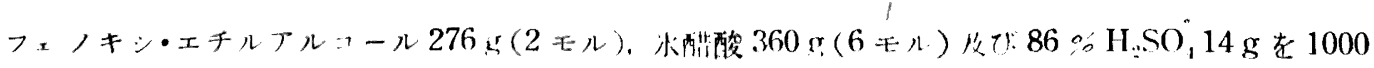

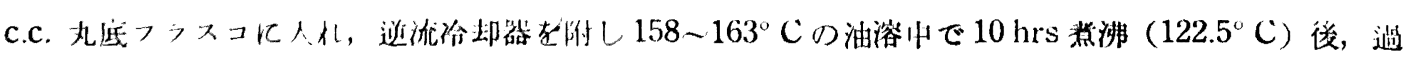

